\title{
Thinking outside the Box
}

\author{
Allan Scott* \\ School of Forensic and Investigative Sciences, University of Central Lancashire, UK
}

Submission: July 26, 2017; Published: July 28, 2017

*Corresponding author: Allan Scott, Lecturer in Forensic Science, School of Forensic and Investigative Sciences, University of Central Lancashire, England, UK, Email: allanscott1504@fastmail.com

\section{Short Communication}

I was one of the first generation of civilian Scenes of Crime Officers (SOCO) in Scotland. I started my twenty six year career with the successor to the oldest police force in the United Kingdom, the City of Glasgow Police. Established in 1800, it was 29 years before Robert Peel established the Metropolitan Police in London. Now called Crime Scene Examiners or Crime Scene Investigators, most CSIs in the United Kingdom are civilians or Police Staff as they are now designated. When I started out, well over two thirds of SOCOs were detectives and I was fortunate enough to be trained alongside them and taught to develop an investigative mind-set. This is following the $\mathrm{ABC}$ of investigation: Assume nothing, Believe no-one and Check everything. Irrespective of whether investigators, including criminalists and forensic scientists are sworn officers or a civilian this mind-set is crucial if they are to truly investigate and not just be forensic magpies, collecting everything but not understanding why.

In the late 1970s, crime scene investigation was almost exclusively fingerprints and photographs. Even today, your box or kit isn't the answer to investigating crime. You have to use the investigative mind-set and think outside the box. This is what investigators in Maricopa County, Arizona did in May 1992. The nude body of young woman found in scrub land, near Phoenix. An eye witness reported seeing a four door pick-up truck speeding away from the scene the previous night. Biological evidence on her body was negated by the suspect's version of events and no other conventional physical or biological evidence was present at the scene. The suspect denied being at the scene, claiming he last saw the deceased alive and running away, having stolen his wallet and pager. With a good defense attorney the eye witness's evidence could easily be called into question.

The body was close to a Palo Verde tree, which has seed pods which can hang low. Visiting the suspect's home, his four door pick-up had Palo Verde pods in the load area. Investigators seized them and made enquiries with the university and found that the new science of DNA applied to plants and not just animals. Recovering pods from one hundred Palo Verde trees, they were able to establish that the pods in the suspect's vehicle came from the tree next to where the deceased was found. When examining everyday items, trainee investigators and forensic investigation students can be blinkered to evidential potential. Everything that is produced has either a serial number or batch number. These aren't there to help investigators but to allow the manufacturers to trace the item's provenance and hopefully avoid or at least mitigate litigation but they are very useful as evidence for investigators.

An example of this is the common soft drinks can or plastic bottle sometimes abandoned at crime scenes. The uninitiated will think "fingerprints" and "DNA" and ignore the batch number. At one homicide I investigated, the main suspect's fingerprints were found on a can. When interrogated, he claimed we would find his prints at the scene as he knew the previous owner of the auto workshop and been a regular visitor up until the business was sold six months prior to the killing. Unfortunately for him we had checked the batch number on the can and the batch only appeared on the shelf of a gas station shop close to the scene three days before the murder.

What most people consider detritus or rubbish can be a goldmine for investigators. Plastic carrier bags in most stores have batch numbers so if a bag bursts on your way to the car, the store will replace any damaged items free of charge and probably invoice the bag manufacturer. Cash register receipts, parking machine tickets, bus tickets whilst possibly not directly related to suspects or scenes can provide valuable intelligence and open leads to CCTV footage that can help identify possible suspects. Crunched up cigarette papers make an ideal way of keeping a note and are easily overlooked in a search of a scene or suspect.

Even consider toilet rolls. The humblest of items have batch and sometimes serial numbers printed on the core. Apparently disgruntled employees weave needles through the ply, hoping to 
cause their employer to be sued for damages! Newspapers can have different editions in a day and establishing where copies were delivered or sold could help either include or exclude suspects.

One phrase I use when training and teaching is “Don't look at what's there - see what's there. A former student called me to tell me she had been hired by a major police force and claimed it was down to my Scots accent and what she previously thought was a silly phrase. At the pre-interview assessment exercise, when told she had two minutes, she heard me in her head and looked around the apartment room. On the bookshelf she noticed a "Yellow Pages" and removing it she found it had a cut out containing an automatic pistol. Apparently she was the only student to find it. When looking at a photograph of a suspect or missing person, examine what's behind them. It could be a clue to their regular of favorite haunts.
Finally, a demonstration we carry out with students at university. We call it "pure jeanius". Unlike other cloth, which is spun, dyed and then woven, blue denim is spun, woven and then dyed. This causes the material to have unique colour variations especially along seams which are almost like almost like a barcode. Several years investigators found this out when trying to get evidence against a bank robber whose mask concealed his face. His jeans were compared to photographs of the offenders at the robbery and it was determined that his jeans had the same patterns of discoloration as those worn at the crime scene, whist 100 pairs of similar jeans were all totally different. We invite students to bring a pair of blue jeans to the lecture and demonstrate it is not a myth. It is prudent to always open your mind and look beyond the obvious.

\section{Your next submission with Juniper Publishers will reach you the below assets}

- Quality Editorial service

- Swift Peer Review

- Reprints availability

- E-prints Service

- Manuscript Podcast for convenient understanding

- Global attainment for your research

- Manuscript accessibility in different formats (Pdf, E-pub, Full Text, Audio)

- Unceasing customer service

Track the below URL for one-step submission https://juniperpublishers.com/online-submission. 